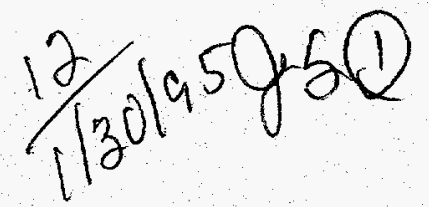

UCRL-ID-118009

\section{Field-Based Tests of Geochemical Modeling Codes Using New Zealand Hydrothermal Systems}

\author{
Carol J. Bruton
}

William E. Glassley

William L. Bourcier

June 1994

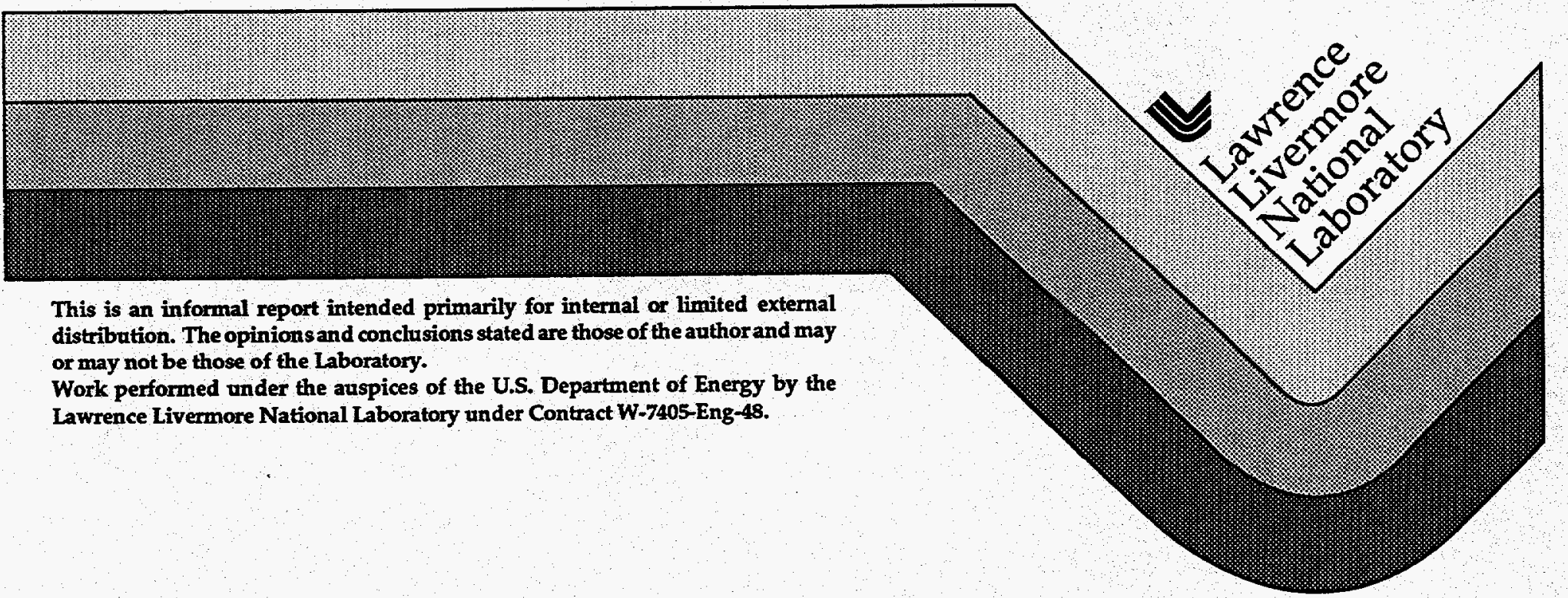




\section{DISCLAIMER}

This document was prepared as an account of work sponsored by an agency of the United States Government. Neither the United States Government nor the University of California nor any of their employees, makes any warranty, express or implied, or assumes any legal liability or responsibility for the accuracy, completeness, or usefulness of any information, apparatus, product, or process disclosed, or represents that its use would not infringe privately owned rights. Reference herein to any specific commercial products, process, or service by trade name, trademark, manufacturer, or otherwise, does not necessarily constitute or imply its endorsement, recommendation, or favoring by the United States Government or the University of California. The views and opinions of authors expressed herein do not necessarily state or reflect those of the United States Government or the University of California, and shall not be used for advertising or product endorsement purposes.

This report has been reproduced directly from the best available copy.

Available to DOE and DOE contractors from the Office of Scientific and Technical Information P.O. Box 62, Oak Ridge, TN 37831

Prices a vailable from (615) 576-8401, FTS 626-8401

Available to the public from the

National Technical Information Service

U.S. Department of Commerce 5285 Port Royal Rd.

Springfield, VA 22161 


\section{DISCLAIMER}

Portions of this document may be illegible in electronic image products. Images are produced from the best available original document. 


\title{
FIELD-BASED TESTS OF GEOCHEMICAL MODELING CODES USING NEW ZEALAND HYDROTHERMAL SYSTEMS
}

CAROL J. BRUTON, WILLIAM E. GLASSLEY and WILLIAM L. BOURCIER

Lawrence Livermore National Laboratory, L-219, P.O. Box 808, Livermore, CA 94550

\begin{abstract}
Hydrothermal systems in the Taupo Volcanic Zone, North Island, New Zealand are being used as field-based modeling exercises for the $\mathrm{EQ} 3 / 6$ geochemical modeling code package. Comparisons of the observed state and evolution of the hydrothermal systems with predictions of fluid-solid equilibria made using geochemical modeling codes will determine how the codes can be used to predict the chemical and mineralogical response of the environment to nuclear waste emplacement. Field-based exercises allow us to test the models on time scales unattainable in the laboratory.

Preliminary predictions of mineral assemblages in equilibrium with fluids sampled from wells in the Wairakei and Kawerau geothermal field suggest that affinity-temperature diagrams must be used in conjunction with EQ6 to minimize the effect of uncertainties in thermodynamic and kinetic data on code predictions.
\end{abstract}

\section{INTRODUCTION}

Active hydrothermal systems can be used as field-based tests of geochemical modeling codes such as EQ3/6. ${ }^{1,2}$ In the Taupo Volcanic Zone (TVZ), North Island, New Zealand, heated fluids have been reacting with silicic rocks, volcanic glasses and man-made materials in hydrothermal systems for long periods of time. Many physical and chemical processes hypothesized to occur in a potential nuclear waste repository such as mineral dissolution/precipitation, changing fluid chemistry, boiling, condensation, fluid flow, glass alteration and degradation of man-made materials, are occurring in various parts of the TVZ thermal systems. The extent to which computer codes adequately represent natural processes relevant to siting of a nuclear waste repository can be tested by comparing computer simulations of fluid-solid interactions with compositional data from these hydrothermal systems.

Comparisons of the observed state and evolution of a hydrothermal system with predictions of fluid-solid equilibria made using geochemical modeling codes will: 1) ensure that we are providing adequately for all significant processes occurring in natural systems; 2 ) determine the adequacy of the mathematical descriptions of the processes; 3 ) check the adequacy and completeness of thermodynamic data as a function of temperature for solids, aqueous species and gases; and 4) determine the sensitivity of model results to the manner in which the problem is conceptualized by the user and then translated into constraints in the code input. The exercises will be used to find ways to minimize the effect on model results of unavoidable uncertainties in field observations and thermodynamic and kinetic data required to run the computer models. Our intent is not to use TVZ hydrothermal systems as total system performance analogues, but to use them to test selected process modules in EQ3/6.

During the course of this project, developments and/or refinements required in EQ3/6 and its 
thermodynamic data base will be identified. This information can then be used to constructively guide and prioritize future code development. The project also affords the opportunity to examine in a field-scale setting the consequences of physical and chemical phenomena that are anticipated in repository performance. In the process of testing the geochemical models in situations that are relevant to the repository, we identify areas where the process of interest occurs based on existing data. Additional data are then collected, if necessary, to better define the processes and their impact on the environment. Not only does such data define the "ground truth" for the models, but it is also extremely useful information in its own right that can be used to forecast system response to various repository scenarios.

\section{SUITABILITY OF NEW ZEALAND HYDROTHERMAL AREAS}

Hydrothermal systems in the Taupo Volcanic Zone (TVZ) of New Zealand (Figure 1) occur within rock types (silicic volcanics) and at temperatures $\left(-10-300^{\circ} \mathrm{C}\right)$ appropriate to Yucca Mountain scenarios. TVZ hydrothermal systems have been active over about 500,000 years, which spans the time scales important in repository models. Alteration mineralogies include zeolites such as mordenite, clinoptilolite, laumontite and wairakite, clays, feldspars, epidote, and silica polymorphs, all of which have played, or may play, a role in the evolution of the repository host rock.

The New Zealand hydrothermal systems are saturated with fluids, whereas the Topopah Spring member of the Paintbrush tuff and surrounding units at Yucca Mountain are unsaturated. Despite its current unsaturated state, the "extended-dry" hydrologic models of Buscheck and Nitao suggest that extensive portions of the volcanic sequence may be fully saturated over extended periods of time (e.g., ${ }^{4,5}$ ). Such areas will be subject to extensive fluid movement through boiling and condensation, and may create a zone of continual reflux above the repository at fluid saturations greater than the ambient saturations of 0.45 to 0.80 . The saturated systems in New Zealand are thus appropriate analogs to specific hydrological and geochemical regimes that develop due to waste emplacement.

Geochemical modeling codes such as EQ3/6 are designed to simulate fluid-solid reactions in fully saturated systems. Their extension to unsaturated systems, and thus to unsaturated portions of the potential Yucca Mountain repository, has been discussed by Bruton and Viani. ${ }^{6}$ They suggest that water activity in the Topopah Spring member will be greater than 0.9 at fluid saturations as low as 0.2 . This suggests that even if water saturation decreases to 0.5 , the system can be treated thermodynamically as if it were saturated. Nonetheless, it is important to first test the code's ability to simulate fluid-solid reactions in saturated systems before proceeding to unsaturated systems.

Active exploitation of the hydrothermal systems for geothermal power gives us the added advantage of being able to collect additional data, such as fluid and rock samples, as needed. Exploitation has resulted in striking changes in hydrothermal areas which we can use to test our ability to model man-induced perturbations in natural systems. For example, production from the Wairakei borefield has resulted in field drawdown and the formation of a steam zone where water used to exist. Cooler waters are beginning to flow back into rocks which were originally at higher temperature. We are collaborating on this project with scientists from New Zealand's Institute of Geological and Nuclear Sciences (IGNS) who have extensive field, experimental and modeling experiences with hydrothermal systems in the TVZ. 


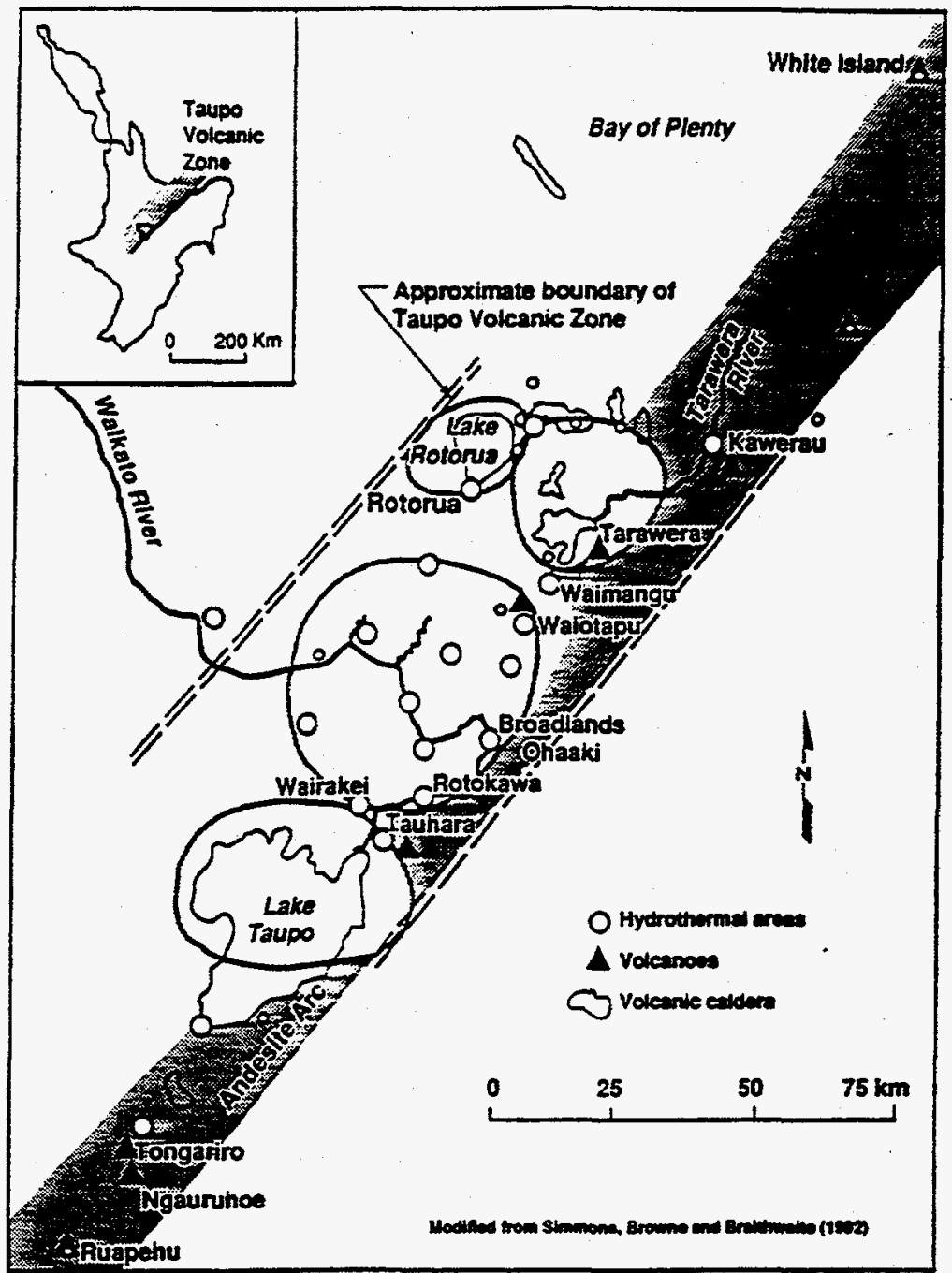

Figure 1. Location map of Taupo Volcanic Zone, North Island, New Zealand with selected hydrothermal areas and volcanic features. Shaded strip represents the andesitic arc. Adapted from ${ }^{3}$.

\section{FIELD-BASED MODELING EXERCISES}

In the exercises described below, the $\mathrm{EQ} 3 / 6$ codes were used to determine the extent to which equilibrium is maintained between a fluid of known composition and a coexisting mineral assemblage. Sets of coexisting water analyses and mineral assemblages along fractures and flow zones were selected from the Wairakei and Kawerau geothermal areas. All calculations were carried out using version $7.1 \mathrm{R} 125$ of EQ3 and version $7.1 \mathrm{R} 154$ of EQ6 together with version R16 of the SUPCRT subset of the GEMBOCHS thermodynamic data base. 1,2 Pressures of all EQ3/6 calculations were set equal to the vapor pressure of water along the liquid/vapor saturation curve.

Fluid chemistry and alteration mineralogy

Alteration mineralogy at Wairakei varies strongly with temperature. Hydrothermal minerals identified at various depths include (excluding the acid condensate zones) epidote, calcite, pyrite, smectite, chlorite and silica polymorphs, plus the zeolites wairakite, mordenite, clinoptilolite and laumontite. $3,7,8$ Water chemistry has changed little throughout the field's $>30$ year production history, except for perturbations such as dilution caused by production. 
Wairakei well WK-28, with a temperature of $248^{\circ} \mathrm{C}$ at the main producing horizon, was chosen for detailed study. Mineral assemblages identified at downhole temperatures of $240-260^{\circ} \mathrm{C}$ in the main feed zones at Wairakei include: wairakite, adularia, epidote solid solutions, wairakite \pm quartz, quartz + adularia, wairakite+epidotetcalcite, albite+quartz+epidote+chlorite+calcite, prehnite and wairakite+prehnite. ${ }^{6}$

The Kawerau hydrothermal field is characterized by higher gas contents than Wairakei. Well KA-21 was selected for the initial study. Vein assemblages at Kawerau and in the feed zones of KA-21 are dominated by quartz, calcite, adularia, pyrite, illite, wairakite, chlorite and epidote solid solutions. ${ }^{9}$ Major differences between the Wairakei and Kawerau assemblages include the ubiquitous presence of calcite at Kawerau and the presence of hydrothermal prehnite at Wairakei but not Kawerau.

The as-sampled composition of the produced waters from WK-28 and KA-21, affected by steam and gas loss during production, is shown in Table 1 . The WK-28 water sample was col-

TABLE 1. Major constituents of discharge from Wairakei well WK-28 sampled on 03/78 (in mg/kg) ${ }^{6}$ and Kaweran well KA-21 (analysis from B. Christenson, pers. comm.)

\begin{tabular}{|c|c|c|c|c|}
\hline Component & $\begin{array}{l}\text { WK-28 } \\
\text { sampled }\end{array}$ & $\begin{array}{l}\text { WK-28 } \\
\text { corrected }\end{array}$ & $\begin{array}{l}\text { KA-21 as- } \\
\text { sampled }\end{array}$ & $\begin{array}{l}\text { KA-21 } \\
\text { corrected }\end{array}$ \\
\hline $\mathrm{Na}$ & 1195 & 846 & 685 & 557 \\
\hline$\overline{\mathbf{K}}$ & 186 & 132 & 107 & 87 \\
\hline $\mathrm{Ca}$ & 19 & 13 & 1.2 & 0.98 \\
\hline $\mathrm{Mg}$ & 0.01 & 0.007 & 0.10 & 0.08 \\
\hline $\mathrm{Fe}$ & NA & $0.58 \mathrm{e}-4$ & NA & $0.75 e-5$ \\
\hline $\mathrm{Al}$ & NA & 0.15 & NA & 0.19 \\
\hline $\mathbf{R b}$ & 2.32 & 1.64 & NA & - \\
\hline $\mathbf{L i}$ & 11.1 & 7.86 & 5.8 & 4.7 \\
\hline Cs & 2.14 & 1.52 & NA & - \\
\hline B & 28.2 & 20 & 46.8 & 38 \\
\hline Cl & 2035 & 1441 & 978 & 796 \\
\hline $\mathrm{HCO}_{3}$ & NA & 102 & 337 & 9389 \\
\hline $\mathrm{SO}_{4}$ & 31 & 22 & 7 & 6.3 \\
\hline $\mathrm{H}_{2} \mathrm{~S}$ & NA & 49 & 26 & 13 \\
\hline $\mathrm{SiO}_{2}$ & 590 & 418 & 702 & 571 \\
\hline $\mathrm{pH}$ & $7.8\left(20^{\circ} \mathrm{C}\right)$ & $5.9\left(248^{\circ} \mathrm{C}\right)$ & $7.27\left(20^{\circ} \mathrm{C}\right)$ & $6.4\left(273^{\circ} \mathrm{C}\right)$ \\
\hline
\end{tabular}

lected at atmospheric pressure, whereas the KA-21 sample was taken at 16.3 bars. The chemical composition of the vapors discharged are shown in Table 2 in units of $\mu \mathrm{mol}$ gas $/ \mathrm{mol}$ water.

Fluid compositions were corrected for the steam and other gases lost because of decreases in pressure during production. Enthalpy balance calculations ${ }^{10}$ were used to estimate the amount of steam loss, which concentrates dissolved species in the produced waters. EQ6 was used to add $\mathrm{CO}_{2}$ and $\mathrm{H}_{2} \mathrm{~S}$, the most reactive and abundant of the gases, back into the fluid. 
TABLE 2. Chemical composition of vapors discharged from Wairakei well WK-28 on $3 / 78{ }^{6}$ and Kawerau well KA.21 (analysis from B. Christenson, pers. comm.) (in $\mu \mathrm{mol} / \mathrm{mol}$ water)

\begin{tabular}{|l||l|l|}
\hline Component & WK-28 & KA-21 \\
\hline $\mathrm{CO}_{2}$ & 30 & 2689.3 \\
\hline $\mathrm{H}_{2} \mathrm{~S}$ & 26.1 & 57.8 \\
\hline $\mathrm{NH}_{3}$ & 1.0 & 59.8 \\
\hline $\mathrm{He}$ & 0.0003 & NA \\
\hline $\mathrm{H}_{2}$ & 0.090 & 5.0 \\
\hline $\mathrm{Ar}$ & 0.014 & NA \\
\hline $\mathrm{O}_{2}$ & $<0.002$ & NA \\
\hline $\mathrm{N}_{2}$ & 0.54 & 32.7 \\
\hline $\mathrm{CH}_{4}$ & 0.095 & 74.9 \\
\hline
\end{tabular}

The recalculated downhole fluid compositions at the downhole temperatures of $248^{\circ} \mathrm{C}$ and $273^{\circ} \mathrm{C}$ are shown in Table $1 . \mathrm{Al}$ and $\mathrm{Fe}$ were assumed to be controlled by equilibrium with respect to ordered K-feldspar and pyrite, respectively, because of the ubiquitous presence of adularia and pyrite at depth in both fields. Redox state was set by the $\mathrm{SO}_{4} / \mathrm{H}_{2} \mathrm{~S}$ buffer, assuming an initial content of $0.3 \mathrm{mg} / \mathrm{kg}$ of aqueous $\mathrm{H}_{2} \mathrm{~S}$ in WK-28 based on concentration data from nearby wells. These assumptions represent the first phase of testing modeling strategies regarding control of redox conditions in the subsurface. Future models will use the fugacity of $\mathrm{H}_{2}(\mathrm{~g})$ to control the ratio of sulfide to sulfate. ${ }^{9}$

\section{Calculation results}

The corrected downhole fluid compositions in Table 1 were used in EQ3 and EQ6 to calculate a measure of the degree of saturation with respect to all potential minerals in the chemical system. The measure of saturation is the affinity for-dissolution or precipitation, defined in $E Q 3 / 6$ as $R T \log (Q / K)$ where $R$ is the gas constant, $T$ is temperature in degrees Kelvin, $Q$ is the ion activity product of the mineral hydrolysis reaction under consideration, and $\mathrm{K}$ is the equilibrium constant at the temperature of interest.

When the affinity of a mineral equals zero, the code predicts that the phase is in equilibrium with the fluid. This does not mean, however, that the mineral necessarily occurs in the actual mineral assemblage. Common ion effects, such as the competition among saturated minerals for available chemical components required for their precipitation, limit the number of minerals that actually will precipitate even though a significantly greater number of minerals may be saturated or supersaturated. The kinetics of precipitation may also impact the appearance of a mineral phase.

Mineral affinities were calculated at temperatures ranging from 200 to $300^{\circ} \mathrm{C}$. Results for selected minerals are shown in Figure 2 for Wairakei WK-28 and Figure 3 for Kawerau KA-21. The downhole temperatures of the fluids can be estimated using Figures 2 and 3 by noting the temperature at which the affinity curves converge on $0 .{ }^{11}$ Minerals shown were selected on the basis of their proximity to saturation and their relevance to subsurface mineralogy.

In this exercise, analyses of solid solutions were used to calculate the activities of end-member components. Clinozoisite represents the clinozoisite component of an epidote solid solution; muscovite refers to the muscovite component in an illite solid solution in Figure 3. In both diagrams, wairakite refers to the phase whose thermodynamic data is from ${ }^{12}$, whereas wairakite-adj. 
(adj.=adjusted) refers to adjustment of the Gibbs free energy of formation of wairakite by -1500 $\mathrm{cal} / \mathrm{mol}$, as suggested by Christenson to better fit observed mineralogical relations at Kawerau. ${ }^{9}$

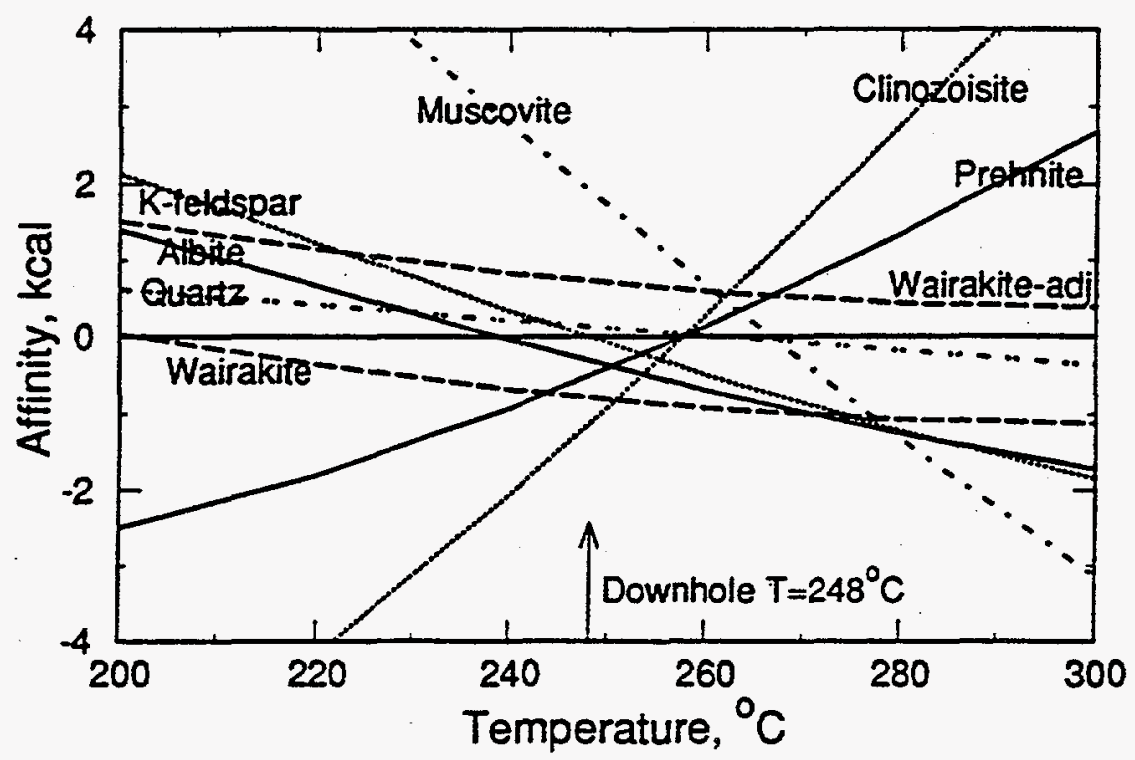

Figure 2. Affinity of selected minerals as a function of temperature in water from Wairakei well WK-28.

A number of minerals appear to be close to equilibrium (within 500 cal) with WK-28 waters at the downhole temperature (Figure 2), including quartz, albite, $\mathrm{K}$-feldspar and prehnite. $\mathrm{K}$-feldspar is in equilibrium at $248^{\circ} \mathrm{C}$ because the fluid was assumed to be in equilibrium with it in order to estimate the concentration of $\mathrm{Al}$ in the fluid. Muscovite is predicted to be supersaturated, even without providing for its reduced activity as a component in an illite solid solution. The wairakite and wairakite with the free energy adjustment span undersaturation and supersaturation. The solution appears to be in equilibrium with the clinozoisite component of the analyzed epidote solid solution.

Figure 3 shows the affinity-temperature relations for KA-21. In comparison to WK-28, prehnite and the clinozoisite component of an epidote solid solution are significantly undersaturated. Hydrothermal prehnite is conspicuousiy absent at Kawerau, in contrast to Wairakei. However, epidote is the most common calc-silicate at Kawerau. Further simulations should explore the impact of boiling on epidote stability. Compositional zoning in epidote seems to record multiple boiling events.

Calcite is about $500 \mathrm{cal} / \mathrm{mol}$ from saturation, much closer than WK-28, in general accordance with its presence at Kawerau. The muscovite component of an illite solid solution is at equilibrium. The free energy adjustment for wairakite does not bring it into equilibrium despite its common occurrence at Kawerau. The impact of boiling must also be explored in this regard. $14 \AA$ clinochlore, which represents a pure $\mathrm{Mg}$ clay, is highly supersaturated, which results from a suspect $\mathrm{Mg}$ analysis. However, it may also reflect the tendency for $\mathrm{Mg}$ to precipitate readily from solution at elevated temperature.

To complement the affinity calculations, EQ6 was used to predict what specific mineral assemblage is stable in equilibrium with each fluid at the downhole temperature. This calculation accounts for competition among supersaturated minerals for available chemical components, but does not take into account kinetics of precipitation. Quartz, muscovite, and pyrite were calculated 


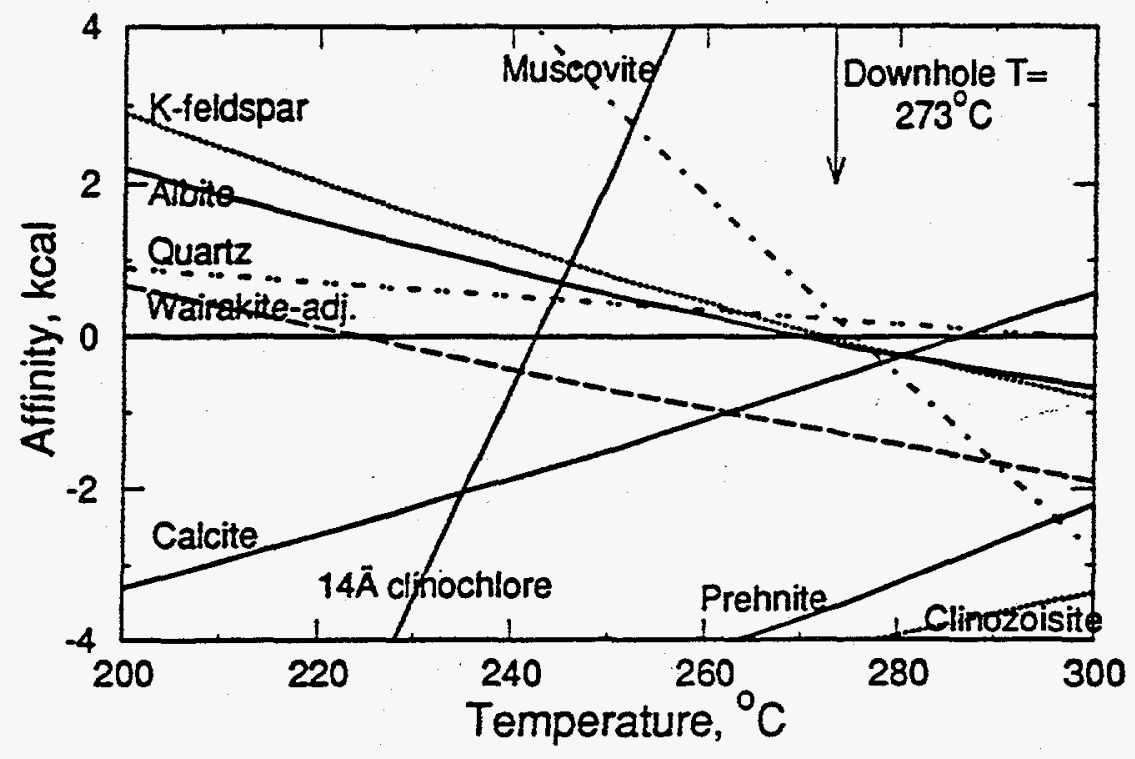

Figure 3. Affinity of selected minerais as a function of temperature in water from Kawerau well KA-21.

to be in equilibrium with the WK-28 fluid. Quartz, talc and pyrite were computed to be the downhole equilibrium mineral assemblage in KA-21. These results do not show how close to equilibrium a number of minerais are. (The affinity of talc plotted in Figure 3 would fall to the left of the curve for $14 \AA$ clinochlore.)

Figures such as Figures 2 and 3 will be important when we try to predict mineral stability from computer simulations. Precipitation of a supersanurated mineral may preclude precipitation of other saturated minerals whose identity would not be apparent from a cursory examination of a simple EQ6 precipitation run. For example, precipitation of Al-bearing muscovite from the WK28 fluid precluded precipitation of K-feldspar, which was initially specified to be in equilibrium with the fluid. If the thermodynamic data for muscovite were suspect, or muscovite was not favored to form because of kinetic constraints, we might never have identified the other minerals as potential precipitates.

Figures 2 and 3 also suggest that a variety of mineral assemblages can be close to equilibrium with a given fluid chemistry. Small energetic differences separate these assemblages, such that small changes in fluid chemistry, temperature or pressure can have a significant impact on mineral assemblages. Perhaps this phenomenon is reflected in the varying combinations of a limited number of minerals noted in Wairakei wells and other hydrothermal areas.

The above results suggest a number of future studies. Additional fluid/mineral assemblage pairs from both hydrothermal fields should be tested to see if the above trends persist. The thermodynamic data for wairakite are still suspect. The mineralogical and chemical consequences of pressure fluctuations, boiling and attendant changes in redox state should be pursued. 


\section{CONCLUDING REMARKS}

The hydrothermal areas of the Taupo Volcanic Zone provide unparalleled opportunities for testing geochemical models of fluid-rock interaction in long-lived natural systems. We are conducting these tests in the TVZ because physical and chemical phenomena operating in the field bear resemblance to potential Yucca Mountain processes. Such phenomena can be used as guides to potential system response to emplacement of nuclear waste in a geologic repository.

Results are being used to define guidelines for making appropriate and reasonable assumptions that will adequately provide for gaps and uncertainties in field data and analytical data, such as the lack of an $\mathrm{Al}$ analysis, or inaccurate $\mathrm{Mg}$ analyses. The controls of equilibrium versus kinetics on mineral precipitation, and the adequacy of the thermodynamic data base are being evaluated by comparing occurrences of hydrothermal minerals with predictions of their stability. Diagrams such as the affinity-temperature diagram allow us to better predict the consequences of fluid-rock interaction by minimizing the effect of uncertainties in thermodynamic data and kinetics of mineral precipitation. Discrepancies between simulations and observations are helping us to identify minerals for which precipitation and dissolution kinetics data may be important.

\section{ACKNOWLEDGEMENTS}

Work performed under the auspices of the U.S. Dept. of Energy by Lawrence Livermore National Laboratory under Contract W-7405-ENG-48. Prepared by Yucca Mountain Site Characterization Project (YMSCP) participants as part of the Civilian Radioactive Waste Management Program. YMSCP is managed by the Yucca Mountain Site Characterization Project Office of the U.S. Dept. of Energy, Las Vegas, Nevada. 


\section{REFERENCES}

1. T.J. Wolery, Lawrence Livermore National Laboratory Report UCRL-MA-110662 PT III (1992). Readily available

2. T.J. Wolery and S.A. Daveler, Lawrence Livermore National Laboratory Report UCRL-MA110662 PT IV (1992). Readily available

3. S.F. Simmons, P.R.L. Browne and R.L. Brathwaite, Active and extinct hydrothermal systems of the North Island, New Zealand, p. 7-8 (Soc. Econ. Geol. Guidebook Vol. 15, Ft. Collins, CO, 1992). MOL.19941013.0063

4. T.A. Buscheck and J.J. Nitao, Proc. of Fourth Intl. High Level Radioactive Waste Mgmt. Conf., p. 847-867 (1993). Readily available

5. W.E. Glassley, C.J. Bruton and W.L. Bourcier, in Scientific Basis for Nuclear Waste Management, this volume. Readily available

6. C.J. Bruton and B.E. Viani, in Water-Rock Interaction 7, p. 705-708, ed. by Y.K. Kharaka and A.S. Maest (A.A. Balkema, Netherlands, 1992). Readily available

7. A. Steiner, New Zealand Geological Survey Bull. 90, p. 43-56 (1977). MOL.19941013.0064

8. A.G. Reyes, W.F. Giggenbach and B.W. Christenson, Inst. of Geol. and Nuclear Sciences Proprietary Report 722305.15.15A (1993). MOL.19941013.0071

9. B. W. Christenson, Ph.D. thesis, p. 262, 333-339, Univ. of Auckland, New Zealand (1987). MOL.19941013.0065

10. R.W. Henley, A.H. Truesdell and P.B. Barton, Jr., Fluid-mineral equilibria in hydrothermal systems, Rev. in Econ. Geol. Vol. 1, p. 15-18 (Soc. of Econ. Geol., Univ. of Texas, El Paso, Texas, 1984). MOL.19941013.0066.

11. M. Reed and N. Spycher, Geochim. et Cosmochim. Acta 48 (1984). MOL.19941013.0067

12. H.C. Helgeson, J.M. Delany, H.W. Nesbitt and D.K. Bird, Am. Jour. Sci. 278-A, p. 124-125 (1978). MOL.19941013.0068 
The following number is for Office of Civilian Radioactive Waste Management Records Management purposes only and should not be used when ordering this document:

Accession Number:

MOL.19940829.0001 